\title{
Anti-Cancer Effect of Metabotropic Glutamate Receptor 1 Inhibition in Human Glioma U87 Cells: Involvement of PI3K/ Akt/mTOR Pathway
}

\author{
Chi Zhang Xian-rui Yuan Hao-yu Li Zi-jin Zhao Yi-wei Liao Xiang-yu Wang \\ Jun Su Shu-shan Sang Qing Liu
}

Department of Neurosurgery, Xiangya Hospital, Central-South University, Changsha, Hunan, China

\section{Key Words}

Metabotropic glutamate receptor $1 \cdot$ Glioma $•$ Apoptosis $•$ Cell cycle $・$ mTOR signaling

\begin{abstract}
Background: Metabotropic glutamate receptors (mGluRs) are G-protein-coupled receptors that mediate neuronal excitability and synaptic plasticity in the central nervous system, and emerging evidence suggests a role of mGluRs in the biology of cancer. Previous studies showed that mGluR1 was a potential therapeutic target for the treatment of breast cancer and melanoma, but its role in human glioma has not been determined. Methods: In the present study, we investigated the effects of mGluR1 inhibition in human glioma U87 cells using specific targeted small interfering RNA (siRNA) or selective antagonists Riluzole and BAY367620. The anti-cancer effects of mGluR1 inhibition were measured by cell viability, lactate dehydrogenase (LDH) release, TUNEL staining, cell cycle assay, cell invasion and migration assays in vitro, and also examined in a U87 xenograft model in vivo. Results: Inhibition of mGluR1 significantly decreased the cell viability but increased the LDH release in a dosedependent fashion in U87 cells. These effects were accompanied with the induction of caspase-dependent apoptosis and G0/G1 cell cycle arrest. In addition, the results of Matrigel invasion and cell tracking assays showed that inhibition of mGluR1 apparently attenuated cell invasion and migration in U87 cells. All these anti-cancer effects were ablated by the mGluR1 agonist L-quisqualic acid. The results of western blot analysis showed that mGluR1 inhibition overtly decreased the phosphorylation of PI3K, Akt, mTOR and P70S6K, indicating the mitigated activation of PI3K/Akt/mTOR pathway. Moreover, the anti-tumor activity of mGluR1 inhibition in vivo was also demonstrated in a U87 xenograft glioma model in athymic nude mice. Conclusion: The remarkable efficiency of mGluR1 inhibition to induce cell death in U87 cells may find therapeutic application for the treatment of glioma patients.
\end{abstract}

C. Zhang and X.-r. Yuana contributed equally to this work.

Copyright $\odot 2015$ S. Karger AG, Basel

Dr. Qing Liu

Department of Neurosurgery, Xiangya Hospital, Central-South University,

Xiangya Road, Changsha, Hunan Province 410008 (China)

Tel. +86-0731-84327113, Fax +86-0731-84327114, E-Mail xiangyaliuqing@163.com 


\section{Introduction}

Gliomas are the most common malignant primary brain tumors in adults, and ranked among the most aggressive human cancers [1]. The World Health Organization (WHO) stratifies gliomas into four grades (I-IV), and the most common and aggressive subtype is glioblastoma (GBM), the grade IV astrocytoma [2]. The median survival of patients diagnosed with GBM is only 14.2 months, and the 5 -year survival rate is only $4.7 \%$ owing to the inevitability of recurrence $[3,4]$. In the past few decades, little progress has been made to treat this cancer with the exception of the addition of temozolomide (TMZ) to the standard of care, which increased the median survival of GBM patients by a mere 2 months [3].

Glutamate is a major excitatory neurotransmitter that regulates cellular and synaptic activity and plasticity through interacting not only with the previously identified ionotropic glutamate-gated ion channels such as the N-methyl-D-aspartate receptors (NMDAR), R-amino-3-hydroxy-5-methyl-4-isoxazole propionate receptors (AMPAR), and kainic acid receptors (KAR), but also with the G protein-coupled metabotropic glutamate receptors (mGluRs) [5, 6]. mGluRs form a family of eight subtypes, mGluR1 to mGluR8, subdivided into three groups (group I, II and III) on the basis of their amino acid sequence, G-protein coupling and pharmacological profile. Activation of group I mGluRs, including mGluR1 and mGluR5, leads to the hydrolysis of phosphatidylinositol-4,5 -bisphosphate (InsP3) and diacylglycerol (DAG) [7, 8]. These receptors have been implicated in diverse neurological pathology, including brain trauma, cerebral ischemia, chronic central pain, amyotrophic lateral sclerosis (ALS), Fragile X syndrome as well as neurodegenerative diseases [9-13].

In addition to the well-established role of glutamate receptors in neurological disorders and neuroprotection, evidence is emerging of a role for these receptors in cancer $[14,15]$. It has been demonstrated that glutamate receptor subunits are expressed in a variety of cancer cell lines and tumors, such as gastric cancer, colorectal cancer, prostate cancer, squamous cell carcinoma and melanoma [16]. The expression of mGluR5 was shown to be associated with better survival of patients with oral squamous cell carcinoma [17], while mGluR4 expression correlated with tumor severity, spreading and recurrence in medulloblastomas [18]. In addition, the impact of mGluR1 for tumor growth was highlighted by experiments showing that creation of a transgenic mouse unexpectedly resulted in a transgenic strain in which melanoma formation developed at high penetrance at a young age [19]. Ectopic expression of mGluR1 in normal melanocytes induced melanocyte hyperproliferation and transformation to malignant tumors [20]. However, the role of mGluR1 in regulating proliferation and progression of human gliomas has not been determined. In the present study, we described an anti-cancer effect of mGluR1 inhibition in human glioma U87 cells by using selective mGluR1 inhibitors as well as small interfering RNA (siRNA) mediated gene knockdown.

\section{Materials and Methods}

\section{Cell culture}

Human glioma U87 cells were obtained from the American Type Culture Collection (Rockville, MD, USA) and cultured in Dulbecco's modified Eagle's medium (DMEM), containing 10\% fetal bovine serum (FBS), $100 \mathrm{U}$ penicillin and $100 \mathrm{U}$ streptomycin at $37^{\circ} \mathrm{C}$ in a humidified incubator of $5 \% \mathrm{CO}_{2}$ and $95 \%$ air.

\section{Short interfering RNA (siRNA) and transfection}

mGluR1 siRNA (sc-61026, Santa Cruz, CA, USA) and control siRNA (sc-37007, Santa Cruz, CA, USA) were dissolved separately in Optimem I (Invitrogen, CA, USA). After $10 \mathrm{~min}$ of equilibration at room temperature, each RNA solution was combined with the respective volume of the Lipofectamine 2000 solution (Invitrogen, CA, USA), mixed gently and allowed to form siRNA liposomes for $20 \mathrm{~min}$. The U87 cells were transfected with the transfection mixture in antibiotic-free cell culture medium for $72 \mathrm{~h}$ before glutamate treatment, and subjected to various measurements.

\section{KARGER}




\section{Immunocytochemistry}

After being fixed with 4\% paraformaldehyde for $15 \mathrm{~min}$ at room temperature, U87 cells were washed with $\mathrm{NaCl} / \mathrm{Pi}$, permeabilized with $0.2 \%$ Triton X-100, and incubated with primary antibodies (anti-mGluR1, 1:100 and anti-mGluR5, 1:100) overnight at $4^{\circ} \mathrm{C}$. Cells were then incubated with Alexa 488-conjugated or Alexa-594-conjugated secondary antibodies for $2 \mathrm{~h}$ at $37^{\circ} \mathrm{C}$, and Hoechst $33342(10 \mu \mathrm{g} / \mathrm{ml})$ was used to stain nucleus. Images were captured with an Olympus FV10i Confocal Microscope (Olympus, Tokyo, Japan). All images of one experiment were acquired with the same exposure time to allow comparisons of relative levels of immunoreactivity between the different treatment conditions. At least six images of each group were taken by an evaluator blinded to the experimental conditions.

\section{Cell viability assay}

Cellviabilityassaywasperformedbyusinga3-(4,5-dimethylthiazol-2-yl)-5-(3-carboxymethoxyphenyl)2-(4-sulfophenyl)-2H-tetrazolium salt (MTS) that can be reduced to purple-coloured formazan by intact cells. After various treatments, cell viability was assessed using the Cell Titer 96 Aqueous One Solution Cell Proliferation Assay Kit (Promega, Madison, WI) according to the manufacturer's instructions. The absorbance was measured with an automatic microplate reader at a wavelength of $492 \mathrm{~nm}$. Results are presented as a percentage of the control.

\section{Lactate dehydrogenase (LDH) release assay}

Cytotoxicity was determined by the release of LDH, a cytoplasmic enzyme released from cells, and a marker of membrane integrity. LDH release into the culture medium was detected with a diagnostic kit (Jiancheng Bioengineering Institute, Nanjing, China) according to the manufacturer's instructions. Briefly, $50 \mu \mathrm{l}$ of supernatant from each well was collected to assay LDH release. The samples were incubated with $\mathrm{NADH}$ and pyruvate for $15 \mathrm{~min}$ at $37^{\circ} \mathrm{C}$, and the reaction was stopped by adding $0.4 \mathrm{M} \mathrm{NaOH}$. The activity of LDH was calculated from the absorbance at $440 \mathrm{~nm}$, and background absorbance from culture medium that was not used for any cell cultures was subtracted from all absorbance measurements. The results were normalized to the maximal LDH release, which was determined by treating control wells for 60 min with $1 \%$ Triton X-100 to lyse all cells.

\section{TUNEL staining}

To investigate the effect of mGluR1 inhibition on apoptotic cell death in U87 cells, TUNEL staining was performed using an in situ cell death detection kit. Briefly, U87 cells were fixed by immersing slides in freshly prepared $4 \%$ methanol-free formaldehyde solution in PBS for $20 \mathrm{~min}$ at room temperature. The cells were then permeabilized with $0.2 \%$ Triton X-100 for $5 \mathrm{~min}$. Cells were labeled with fluorescein TUNEL reagent mixture for $60 \mathrm{~min}$ at $37^{\circ} \mathrm{C}$ according to the manufacturer's suggested protocol (Promega, Madison, WI, USA). Subsequently, the slides were examined by fluorescence microscopy and the number of TUNELpositive (apoptotic) cells was counted. Hoechst $33342(10 \mu \mathrm{g} / \mathrm{ml})$ was used to stain the nucleus.

\section{Assessment of the cell cycle}

U87 cells were treated with control siRNA, mGluR1 siRNA, Riluzole $(50 \mu \mathrm{M})$ or BAY36-7620 (50 $\mu \mathrm{M})$ for 24 or $48 \mathrm{~h}$ at $37^{\circ} \mathrm{C}$. Thereafter, cells were washed, fixed in citrate buffer, and finally incubated for $1 \mathrm{~h}$ at $-20^{\circ} \mathrm{C}$. Cells were next incubated in a glycine/ $\mathrm{NaCl}$ buffer containing $0.1 \%$ Nonidet P- $40,10 \mu \mathrm{g} / \mathrm{ml}$ RNase A, and $40 \mu \mathrm{g} / \mathrm{ml}$ of propidium iodide (PI) for $1 \mathrm{~h}$ at $4^{\circ} \mathrm{C}$. Cell distribution across the different phases of the cell cycle was detected with a FACScan and analyzed.

\section{Matrigel invasion assays}

Invasion assays were performed using Matrigel-coated invasion chambers (BD Biosciences, NJ, USA) in accordance with the manufacturer's protocol. For these experiments, cells were treated with control siRNA, mGluR1 siRNA, Riluzole $(10 \mu \mathrm{M})$ or BAY36-7620 $(10 \mu \mathrm{M})$. Thereafter, cells were plated in the upper chamber of rehydrated Matrigel inserts, serum free media at density of $3 \times 10^{5}$ cells/chamber. U87 cells were allowed to invade the Matrigel matrix overnight towards the bottom chamber containing complete culture media with $10 \%$ FBS. On the next day, the bottom part of the insert was fixed with paraformaldehyde and stained with DAPI (Vectashield) to visualize the nuclei of invaded cells. Ten random pictures of each insert were taken using a Leica DM IRB microscope at $\times 20$ magnification. The number of invaded cells was counted manually. All invasion assays were performed in triplicates and in at least three independent experiments. 


\section{Cell Tracking}

U87 cells were cultured in a $35 \mathrm{~mm}$ dish overnight. The growth medium was changed to Ringer's solution supplemented with $5 \%$ calf serum $2 \mathrm{~h}$ before recording, and cells were maintained at $37^{\circ} \mathrm{C}$ throughout the experiment. The random migration of the cells was recorded with a phase contrast microscope, and traces and migration speed of migrating cells were analyzed with the Meta Morph software (Molecular Devices, CA, USA).

\section{Western blotting}

Equivalent amounts of protein ( $60 \mu \mathrm{g}$ per lane) were loaded and separated by 10\% SDS-PAGE gels, and transferred to polyvinylidene difluoride (PVDF) membranes. Membranes were blocked with $5 \%$ nonfat milk solution in tris-buffered saline with $0.1 \%$ Triton X-100 (TBST) for $1 \mathrm{~h}$, and then incubated overnight at $4^{\circ} \mathrm{C}$ with the primary Pro-PARP, Cleaved-PARP, Pro-caspase-3, Cleaved caspase-3, cyclin D1, CDK 4, p-PI ${ }_{3} \mathrm{~K}$, $\mathrm{PI}_{3} \mathrm{~K}$, p-Akt (Ser473), p-Akt (Thr308), Akt, p-mTOR, mTOR, p-P70S6K, P70S6K, PTEN or $\beta$-actin antibody dilutions in TBST. After that the membranes were washed and incubated with secondary antibody for 1 $\mathrm{h}$ at room temperature. Immunoreactivity was detected with Super Signal West Pico Chemiluminescent Substrate (Thermo Scientific, Rockford, IL, USA). An analysis software named Image J (Scion Corporation) was used to quantify the optical density of each band.

\section{Hematoxylin and eosin staining}

Isolated organ tissues were fixed in formalin and embedded in paraffin. Five micrometer sections were cut and stained with H\&E. All sections were evaluated by an independent observer, who was blinded to the grouping and experimental protocols

\section{Mouse model of tumor xenograft growth}

The U87 xenograft glioma model was established to confirm the anti-tumor effect of mGluR1 inhibition in vivo. Briefly, athymic nude mice ( $4-5$ weeks, $n=18$ ) were anesthetized with ethylcarbamate and injected s.c. with $5 \times 10^{5} \mathrm{U} 87$ cells into the right flanks. As shown in Fig. 7B, mice were randomly divided into control group, Ril group (Riluzole $10 \mathrm{mg} / \mathrm{kg}$ ) and Bay group (Bay 36-7620 $10 \mathrm{mg} / \mathrm{kg}$ ). In another experiment (Fig. 7C), athymic nude mice ( $4-5$ weeks, $n=12$ ) were injected s.c. with $5 \times 10^{5}$ U87 cells expressing control siRNA (Si-control) or mGluR1 targeted siRNA (Si-mGluR1) into the right flanks. Tumor volume was measured every two days from day 6 and calculated by the following formula: $0.4 \mathrm{x}$ length $\mathrm{x}$ width².

\section{Statistical analysis}

Statistical analysis was performed using SPSS 16.0, a statistical software package. Statistical evaluation of the data was performed by one-way analysis of variance (ANOVA). A value of $P<0.05$ was considered statistically significant.

\section{Results}

\section{Anti-cancer effects of mGluR1 inhibition in U87 cells}

To investigate the role of mGluR1 in regulating cell growth in human glioma cells, U87 cells were transfected with specific mGluR1 targeted siRNA (Si-mGluR1) or a nonslicing control siRNA (Si-control), after which the expression of mGluR1 and mGluR5 were examined by western blot analysis (Fig. 1A). The mGluR1 expression was inhibited by SimGluR1 compared to Si-control, but the expression of mGluR5 was not altered. We also detected the expression of mGluR1 and mGluR5 by fluorescence staining (Fig. 1B), and the level of mGluR1 protein was significantly decreased by Si-mGluR1 transfection. However, the expression level and distribution of mGluR5 were unaffected by Si-mGluR1 transfection. In addition, we also treated U87 cells with Riluzole (Ril) and Bay 36-7620 (Bay), two selective mGluR1 antagonists, and the biological function of mGluR1 was measured by cell viability and LDH release assays after siRNA transfection and antagonist treatment. As shown in Fig. 1C and 1D, mGluR1 inhibition markedly decreased cell viability but increased LDH release in human glioma U87 cells, although mGluR1 antagonists were not effective at 10 and $20 \mu \mathrm{M}$ in LDH assay $(P>0.05)$. Temozolomide (TMZ) at $400 \mu \mathrm{M}$ was used as a positive control.

\section{KARGER}




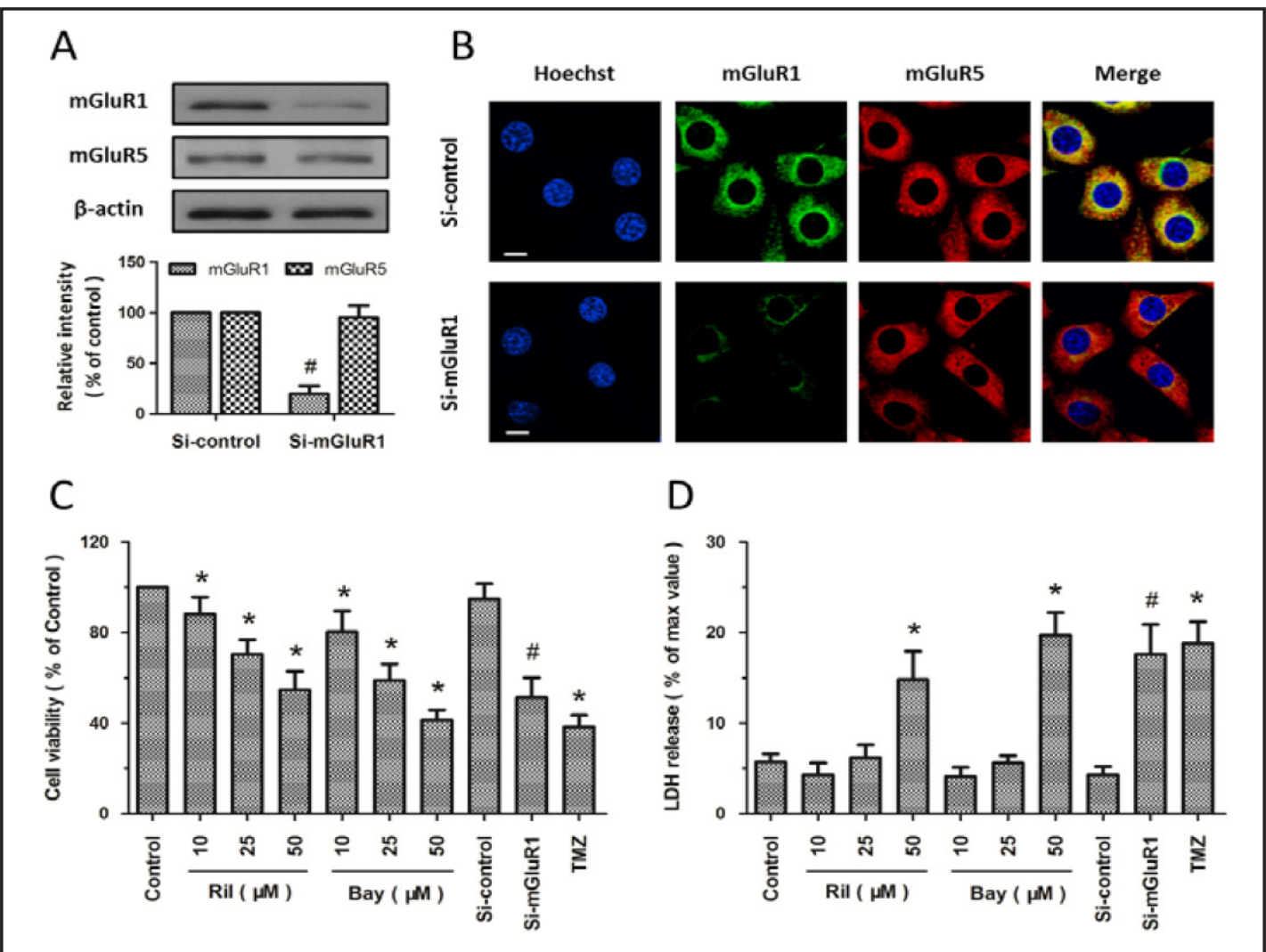

Fig. 1. Inhibition of mGluR1 suppresses cell proliferation in U87 cells. U87 cells were transfected with mGluR1 specific siRNA (Si-mGluR1) or control siRNA (Si-control) for $72 \mathrm{~h}$, and the expression of mGluR1 and mGluR5 was assayed by western blot analysis (A). The distribution of mGluR1 and mGluR5 in U87 cells after transfection were detected by immunofluorescence (B). U87 cells were transfected with Si-mGluR1 or Si-control for $72 \mathrm{~h}$ or treated with mGluR1 inhibitor Riluzole (Ril) or BAY36-7620 (Bay) at different concentrations for $24 \mathrm{~h}$. The cell viability was measured by WST-1 assay (C), and the cytotoxicity was measured by LDH release assay (D). Temozolomide (TMZ) at $400 \mu \mathrm{M}$ was used as a positive control. Scale bar: $10 \mu \mathrm{M}$. Data are shown as mean \pm SD of five experiments. ${ }^{*} p<0.05$ vs. Control group. ${ }^{\#} p<0.05$ vs. Si-control group.

\section{Inhibition of mGluR1 induces apoptosis in U87 cells}

To determine whether the anti-cancer effect of mGluR1 inhibition was due to inducing apoptotic cell death, U87 cells was transfected with Si-mGluR1 or treated with mGluR1 inhibitors (Riluzole $50 \mu \mathrm{M}$ or BAY36-7620 $50 \mu \mathrm{M}$ ). As shown in Fig. 2A, TUNEL staining was used to detect apoptosis, and the results showed that both mGluR1 inhibitors and mGluR1 knockdown significantly increased the apoptotic rate in U87 cells (Fig. 2B). We also detected the activation of PARP and caspase-3, two pro-apoptotic factors, by western blot analysis (Fig. 2C). The results showed that the expression of cleaved PARP and cleaved caspase-3 were both increased by Riluzole or BAY36-7620, whereas the expression of pro-PARP and pro-caspase-3 were not altered as compared to control group (Fig. 2D). A similar result in pro-PARP, cleaved-PARP, pro-caspase- 3 and cleaved caspase- 3 expression after mGluR1 knockdown compared with Si-control transfected group was also observed (Fig. 2D).

Inhibition of mGluR1 induces G1 cell cycle arrest in U87 cells

The percentage of cells in individual cell-cycle phases was assessed after mGluR1 knockdown or incubation with mGluR1 inhibitors. Representative histograms at $24 \mathrm{~h}$ and $48 \mathrm{~h}$ are shown in Fig. 3A and 3B. A marked decrease of the cell fraction with fully replicated DNA (G2/M) occurs within $24 \mathrm{~h}$ after Riluzole or BAY36-7620 addition. This corrected with an increased proportion of cells in the G0/G1 phase of the cell cycle (Fig. 3A). After $48 \mathrm{~h}$ of 


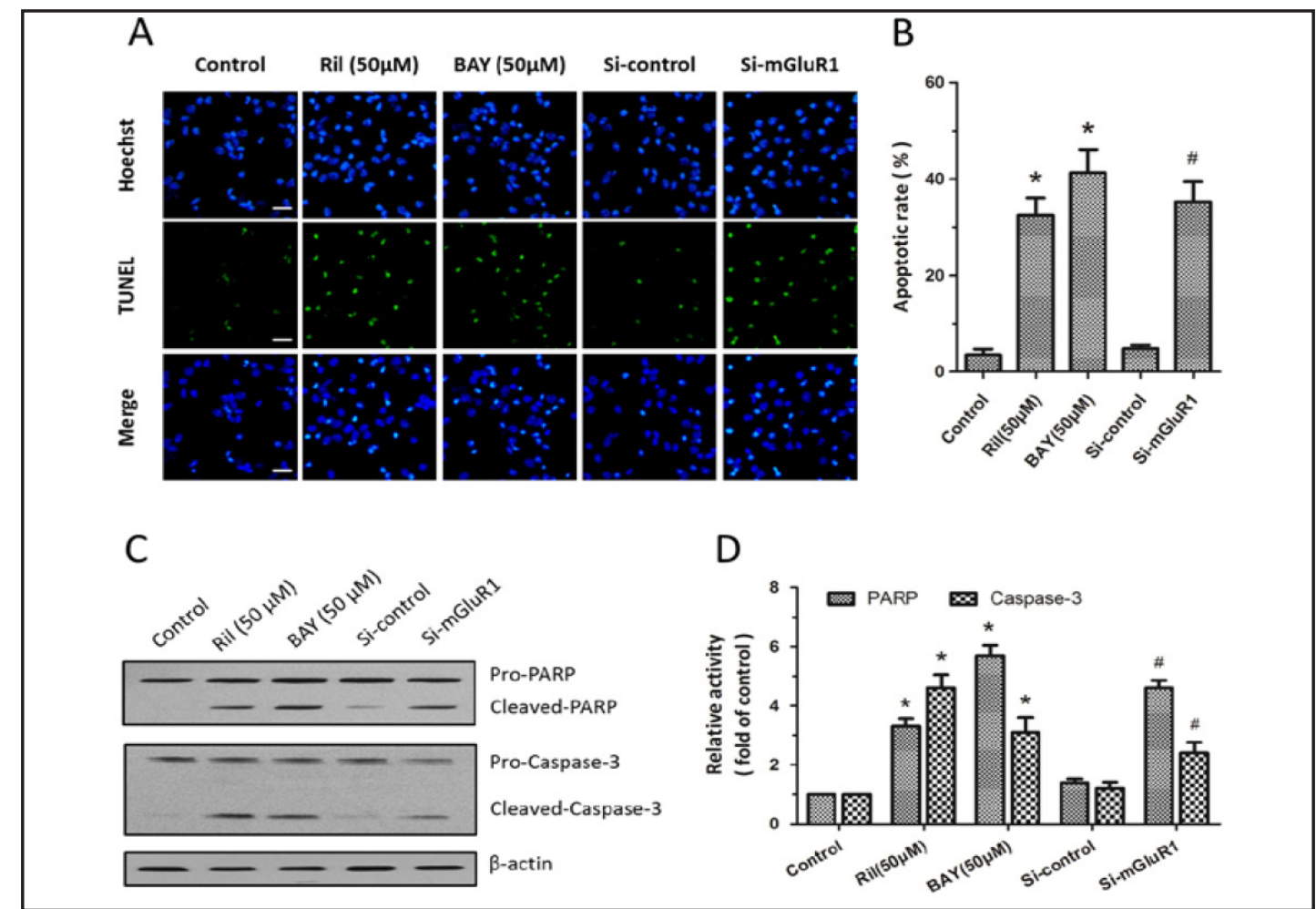

Fig. 2. Inhibition of mGluR1 induces apoptosis in U87 cells. U87 cells were transfected with Si-mGluR1 or Si-control for $72 \mathrm{~h}$ or treated with mGluR1 inhibitor Riluzole (Ril, $50 \mu \mathrm{M}$ ) or BAY36-7620 (Bay, $50 \mu \mathrm{M}$ ) for $24 \mathrm{~h}$. Apoptotic cell death was measured by TUNEL staining (A), and the apoptotic rate was calculated (B). The expression of PARP and Caspase- 3 was detected by western blot analysis (C), and the activities of PARP and Caspase- 3 were calculated (D). Scale bar: $50 \mu \mathrm{M}$. The data was represented as means \pm SD from five experiments. ${ }^{*} p<0.05$ vs. Control group. ${ }^{*} p<0.05$ vs. Si-control group.

Fig. 3. Inhibition of $\mathrm{mG}$ luR1 induces G1 cell cycle arrest in U87 cells. U87 cells were transfected with Si-mGluR1 or Si-control for $72 \mathrm{~h}$ or treated with mGluR1 inhibitor Riluzole (Ril, $50 \mu \mathrm{M}$ ) or BAY36-7620 (Bay, 50 $\mu \mathrm{M})$. The percentage of cells in individual cell-cycle phases was assessed at $24 \mathrm{~h}$ (A) and $48 \mathrm{~h}$ (B). The expression of cyclin D1 (C) and CDK 4 were measured by western blot analysis. The data was represented as means \pm SD from five experiments. ${ }^{*} p$ $<0.05$ vs. Control group. ${ }^{\#} p<0.05$ vs. Si-control group.

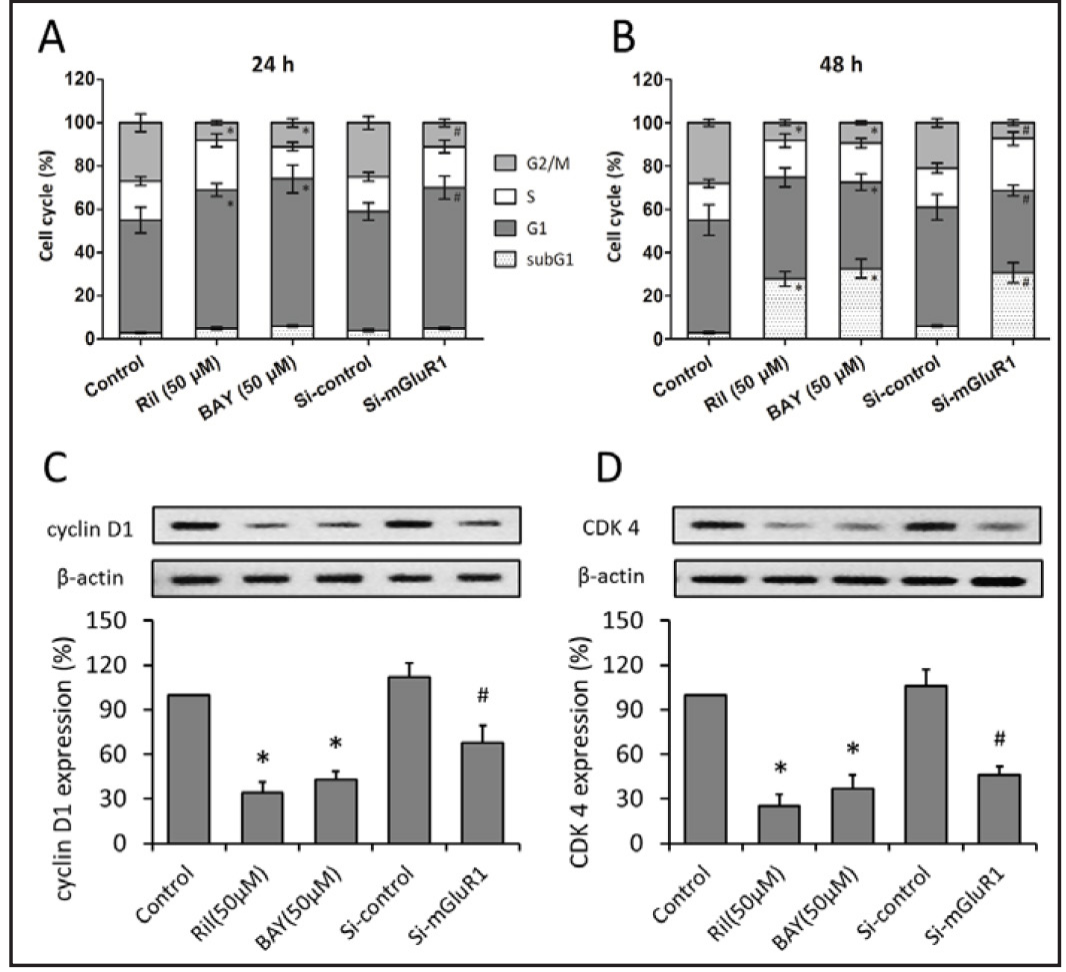




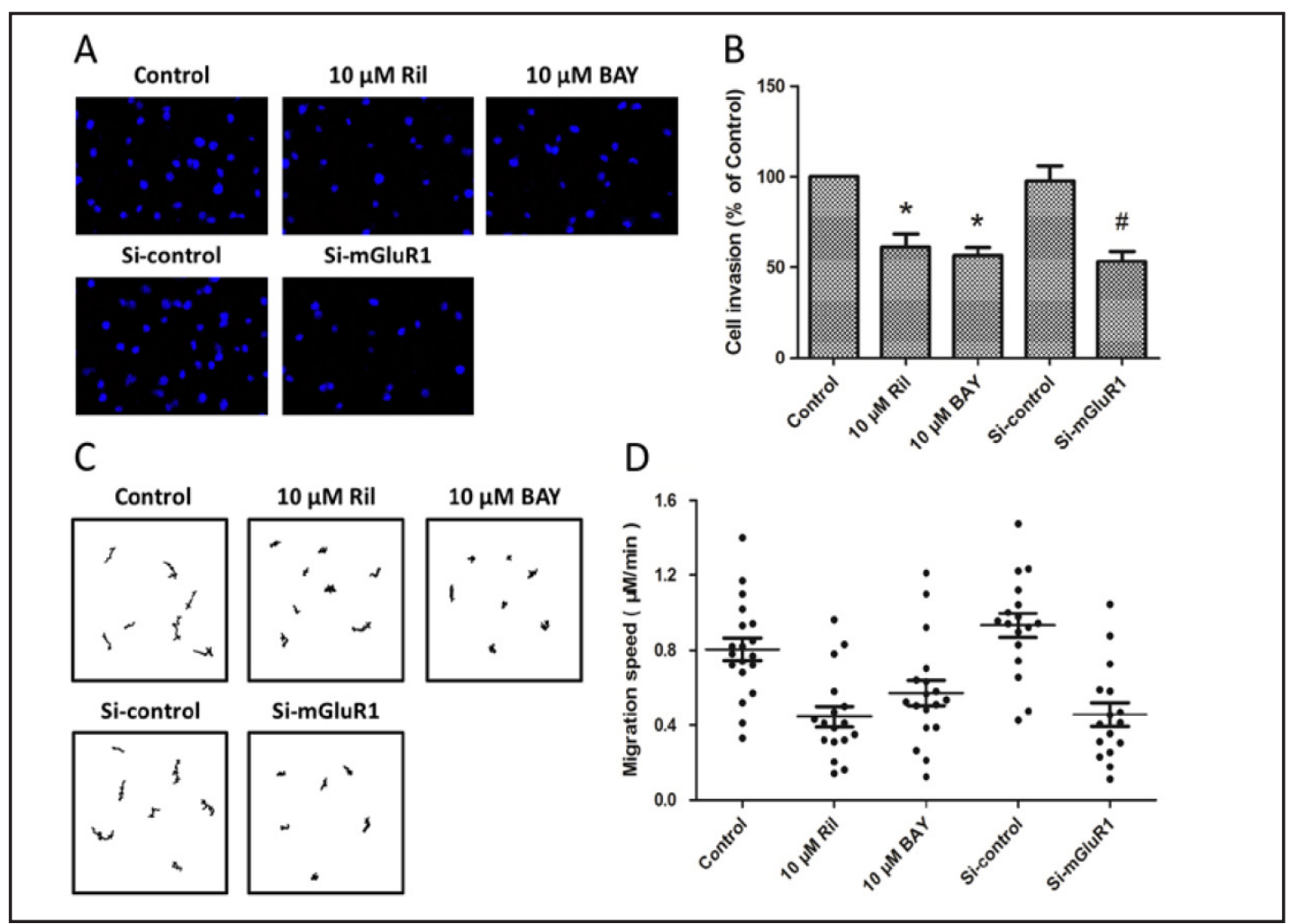

Fig. 4. Inhibition of mGluR1 regulates invasion and migration in U87 cells. U87 cells were transfected with Si-mGluR1 or Si-control for $72 \mathrm{~h}$ or treated with mGluR1 inhibitor Riluzole (Ril, $10 \mu \mathrm{M}$ ) or BAY36-7620 (Bay, $10 \mu \mathrm{M}$ ). Invasion of U87 cells was detected by Mtrigel invasion assay (A), and calculated (B). Migrating traces were obtained by tracking the movement of U87 cells over the course of $2 \mathrm{~h}(\mathrm{C})$, and cell migration speed of U87 cells was calculated from cell tracking (D). The data was represented as means \pm SD from five experiments. ${ }^{*} p<0.05$ vs. Control group. ${ }^{*} p<0.05$ vs. Si-control group.

mGluR1 inhibitors incubation, a significant fraction of U87 cells accumulated in the subG1 phase together with a drastic reduction of the percentage of cells in the G2/M phase of the cell cycle (Fig. 3B). A similar result in cell cycle distribution after mGluR1 knockdown compared with Si-control transfected group was also observed. In addition, we also detected the expression of cyclin D1 and CDK4, two important cell cycle regulatory proteins, by western blot analysis (Fig. 3C and 3D). As expected, we observed that mGluR1 inhibition by both mGluR1 inhibitors and siRNA transfection significantly decreased the expression of cyclin D1 and CDK4.

\section{Inhibition of $m$ GluR1 regulates invasion and migration in U87 cells}

We next used the Matrigel invasion assay with serum as a chemo-attractant to explore the role of mGluR1 in glioma cell invasion (Fig. 4A). As shown in Fig. 4B, silencing of mGluR1 by specific siRNA transfection potently reduced the invasion of U87 cells. Treatment with Riluzole or BAY36-7620 also decreased the ability of U87 cells to invade the Matrigel matrix in the range of $53-61 \%$ (Fig. $4 \mathrm{~B}, P<0.01$ ). In addition, we also detected the cell migration using live-cell tracking assay (Fig. 4C). The results showed that si-mGluR1 transfection significantly decreased the migration speed of U87 cells by $~ 50 \%$ as compared with control siRNA transfected cells (Fig. 4D). A similar result was also observed in Riluzole or BAY367620 treated U87 cells compare to control cells.

mGluR1 agonist reverses anti-cancer activity of mGluR1 inhibition

To determine whether the results observed in our study were due to the inhibition of mGluR1 receptor activity, U87 cells were stimulated with the selective mGluR1 agonist, 


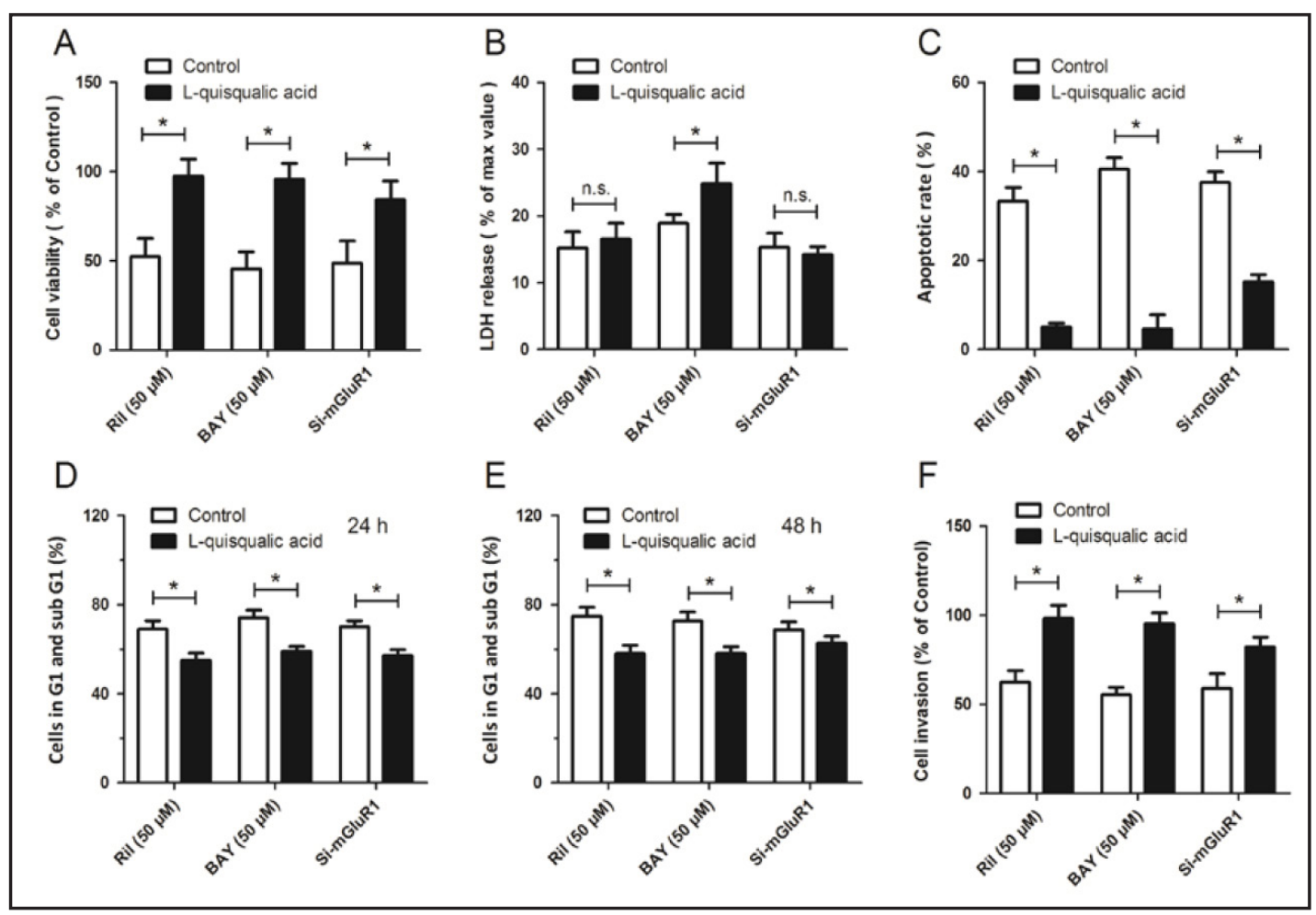

Fig. 5. mGluR1 agonist reverses anti-cancer activity of mGluR1 inhibition. U87 cells were transfected with Si-mGluR1 or treated with mGluR1 inhibitor Riluzole (Ril, $50 \mu \mathrm{M})$ or BAY36-7620 (Bay, $50 \mu \mathrm{M})$ in the presence or absence of mGluR1 agonist L-quisqualic acid $(10 \mu \mathrm{M})$. The cell viability (A), LDH release (B), apoptosis (C), cell cycle (D and E) and cell invasion (F) were assayed. The data was represented as means \pm SD from five experiments. ${ }^{*} p<0.05$. n.s., not statistically significant.

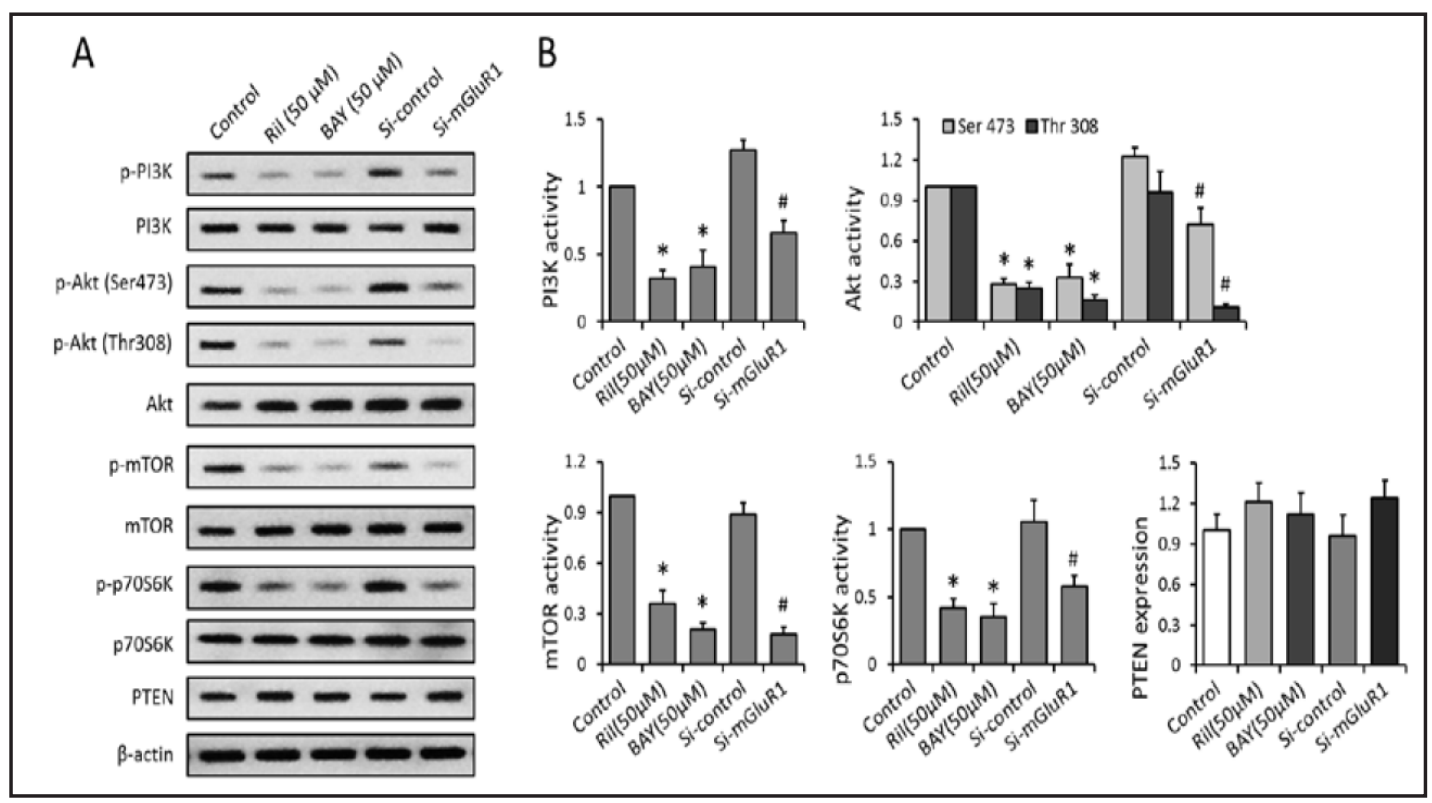

Fig. 6. Effects of mGluR1 inhibition on the activation of PI3K/Akt/mTOR signaling. U87 cells were transfected with Si-mGluR1 or Si-control for $72 \mathrm{~h}$ or treated with mGluR1 inhibitor Riluzole (Ril, $50 \mu \mathrm{M}$ ) or BAY367620 (Bay, $50 \mu \mathrm{M}$ ). The expression of PI3K/Akt/mTOR signaling factors (PI3K, Akt, mTOR, p70S6K and PTEN) were detected by western blot analysis (A) and calculated (B). The data was represented as means \pm SD from five experiments. ${ }^{*} p<0.05$ vs. Control group. ${ }^{*} p<0.05$ vs. Si-control group. 


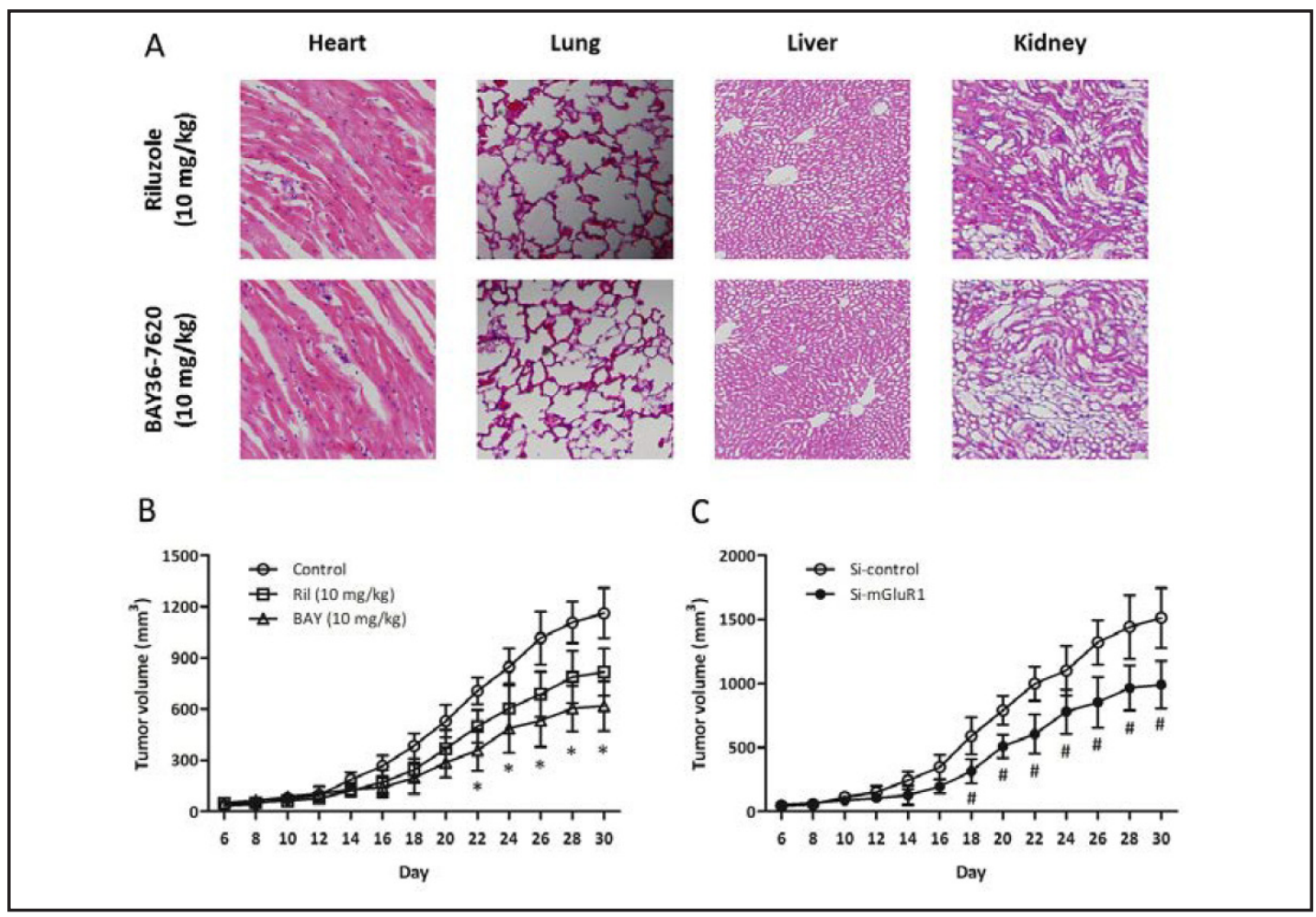

Fig. 7. Anti-tumor effect of mGluR inhibition in U87 xenograft glioma model. The mice were intraperitonealy treated with Riluzole $(10 \mathrm{mg} / \mathrm{kg}$ ) or BAY36-7620 (10 mg/kg) every day for 30 days. After the experiment, animals were sacrificed and the organs were fixed in formalin overnight and processed for paraffin embedding. The paraffin-embedded blocks were sectioned and stained by hematoxylin and eosin (A). The athymic nude mice were treated with mGluR1 inhibitor Riluzole (Ril, 10 mg/kg) or BAY36-7620 (Bay, 10 $\mathrm{mg} / \mathrm{kg}$ ) by intraperitoneal administration every day following U87 cell injection, and the tumor volume was monitored from 6 to 30 days later (B). The athymic nude mice were injected with Si-mGluR1 transfected U87 cells or Si-control transfected U87 cells, and the tumor volume was monitored from 6 to 30 days later (C). The data was represented as means \pm SD from six experiments. ${ }^{*} p<0.05$ vs. Control group. ${ }^{*} p<0.05$ vs. Si-control group.

L-quisqualic acid $(10 \mu \mathrm{M})$, either in the presence or absence of inhibitors treatment and siRNA transfection. The results showed that treatment with L-quisqualic acid partially nullified mGluR1 inhibition induced anti-cancer effects in U87 cells, as evidenced by increased cell viability (Fig. 5A), decreased LDH release (Fig. 5B) and apoptotic cell death (Fig. 5C), although there was no significant differences in LDH release in Riluzole treated and Si-mGluR1 transfected cells. We also measured the percentage of cells in G1 and sub G1 cell-cycle phases at $24 \mathrm{~h}$ and $48 \mathrm{~h}$, and the results showed that L-quisqualic acid treatment significantly decreased the percentage of cells in G1 and sub G1 at both $24 \mathrm{~h}$ and $48 \mathrm{~h}$ induced by mGluR1 inhibition (Fig. 5D and 5E). A similar result in cell invasion was also observed (Fig. 5F).

\section{Effects of mGluR1 inhibition on the activation of PI3K/Akt/mTOR signaling}

We then tested whether treatment with Riluzole or BAY36-7620, or transfection with mGluR1 targeted siRNA could induce inhibition of $\mathrm{PI}_{3} \mathrm{~K}$ activity in U87 cells by western blot analysis (Fig. 6A). After various treatments, cell lysates were immune -precipitated with phosphorylated or total $\mathrm{PI}_{3} \mathrm{~K}$ antibody, and U87 cells showed significantly inhibited phosphorylation of $\mathrm{PI}_{3} \mathrm{~K}$ after mGluR1 blocking (Fig. 6B). The inhibition of $\mathrm{PI}_{3} \mathrm{~K}$ in U87 cells after mGluR1 inhibition resulted in inhibition of Akt, which is one of the major downstream targets of $\mathrm{PI}_{3} \mathrm{~K}$. As expected, antagonists treatment or siRNA transfection successfully KARGER 
inhibited phosphorylation of Akt at both Ser473 and Thr308 residues. Also, mGluR1 inhibition decreased the expression levels of phosphorylated mTOR and P70S6K, one of the best characterized targets of mTOR complex, whereas the total protein levels of these two molecules were not altered (Fig. 6B). In contrast, the expression of PTEN was not changed by antagonists treatment or siRNA transfection. All these data provided strong evidence that activation of $\mathrm{PI}_{3} \mathrm{~K} / \mathrm{Akt} / \mathrm{mTOR}$ pathway was suppressed after mGluR1 inhibition.

\section{Anti-tumor effect of mGluR inhibition in U87 xenograft glioma model}

To determine the tumor growth inhibition effects of mGluR1 inhibition in vivo, we first detected the cytotoxic effects of Riluzole and BAY36-7620 on normal tissues. As shown in Fig. $7 \mathrm{~A}$, mice were intraperitonealy treated with Riluzole $(10 \mathrm{mg} / \mathrm{kg})$ or BAY36-7620 $(10 \mathrm{mg} /$ $\mathrm{kg}$ ) every day for 30 days, and H\&E staining of the organs collected form our experiments suggested no major organ related toxicities (Fig. 7A). We used an U87 xenograft model in which tumor-bearing mice were treated with $10 \mathrm{mg} / \mathrm{kg}$ Riluzole or $10 \mathrm{mg} / \mathrm{kg}$ BAY36-7620 by intraperitoneal administration every day after U87 cell injection, and the tumor volume was monitored from 6 to 30 days later. As shown in Fig. 7B, statistical differences in tumor volume were observed between mGluR1 antagonists group and control group from 22 to $30 \mathrm{~d}$. We also used another strategy, in which the athymic nude mice were injected with Si-mGluR1 transfected U87 cells or Si-control transfected U87 cells, and the tumor volume was monitored from 6 to 30 days later (Fig. 7C). The results showed that the average tumor volume in Si-mGluR1 group was significantly smaller than the Si-control group.

\section{Discussion}

There are two major findings from this study: (1) identification of mGluR1 as a potential therapeutic target for the treatment of human gliomas, as evidenced by cell viability, apoptosis, cell invasion and migration assays, and (2) discovery of the molecular mechanism underlying mGluR1 inhibition induced anti-cancer effect that mediated by $\mathrm{PI}_{3} \mathrm{~K} / \mathrm{Akt} / \mathrm{mTOR}$ pathway. These conclusions are supported by using selective mGluR1 antagonists Riluzole and BAY36-7620, as well as gene silencing experiments performed with siRNA constructs. They are also corroborated by independent measurements of in vivo tumor growth using an U87 cell xenograft model.

Signaling through mGluRs and downstream signaling cascades play important roles in the CNS, but it has not been determined whether dysregulation of the activity of these receptors can lead to growth and progression of cancer. In contrast to iGluRs, which mediate direct and fast information transfer at postsynaptic density, mGluRs either tune neuronal excitability at the postsynaptic level or control neurotransmitter release at presynaptic area [21]. There is a growing body of evidence showing that mGluRs activated by endogenous glutamate are involved in the regulation of both excitatory and inhibitory neurotransmission, thereby modulating network activity, with obvious implications for high brain functions [22, 23]. Moreover, targeting iGluRs by using selective agonists and antagonists or using gene silence can only alleviate symptoms for a few CNS disorders, and none of these drugs has been successfully transformed into clinical practice, which might be explained by their side effects on other signaling cascades, such as intracellular calcium metabolism, protein kinase system activities and opening of other cation channels [24]. Thus, mGluRs might be an ideal therapeutic target for the treatment of neurological disorders, including brain tumors.

Given that mGluR1 is actively involved in the regulation of normal cellular activity and synaptic plasticity, orthosteric and allosteric modulation of the receptor is considered to be of potential therapeutic interest for many indications [5, 25]. Molecular antagonist intervention at mGluR1 has been demonstrated to be effective in many neurological disorders, such as stroke, brain trauma, epilepsy, anxiety, drug addiction and neurodegeneration [26]. Antagonists of mGluR1 can be divided into two groups: the glutamate derived selective competitive antagonists and the negative noncompetitive mGluR1 modulators (allosteric 
antagonists) $[27,28]$. The natural consequence of competitive antagonists, the structural similarity to the endogenous agonist glutamate, is the difficulty in making highly subtype selective glutamate antagonists, with unsurprising side effects on mGluR5, group II or Group III mGluRs [25]. The identification of nonglutamate binding mGluR1 allosteric modulators, such as BAY36-7620 and Riluzole, improves the chances of identifying mGluR subtype selective molecules with better drug-like properties [29]. BAY36-7620 is a potent, noncompetitive mGluR1 antagonist, and inhibits $>60 \%$ of mGlu1a receptor constitutive activity without displacement of the $\left[{ }^{3} \mathrm{H}\right]$ quisqualate binding from the glutamate-binding pocket [30]. The specific site of action of BAY36-7620 differs from that of competitive antagonists and it has been widely used to delineate the functional importance of the mGluR1 with its putative agonist-independent activity [31,32]. Importantly, Riluzole is an FDA-approved orally available drug that is commonly used for the treatment of amyotrophic lateral sclerosis (ALS) [33, 34]. In the present study, BAY36-7620 and Riluzole were used to determine the role of mGluR1 in human gliomas, and these two compounds were demonstrated to inhibit proliferation, invasion and migration of U87 cells in vitro, and also alleviated tumor growth in vivo, which was consistent with previous reports on melanoma progression [35, 36]. Using these orally available drugs and the in vivo experiments are of great relevance to clinical practice.

The $\mathrm{PI}_{3} \mathrm{~K}-\mathrm{Akt}-\mathrm{mTOR}$ pathway is crucial to many aspects of cell growth and survival, in physiological as well as in pathological conditions, including cancer [37, 38]. $\mathrm{PI}_{3} \mathrm{~K}$ constitutes a lipid kinase family characterized by the capability to phosphorylate inositolring 3'-OH group in inositol phospholipids [39]. It can recruit a subset of signaling proteins with pleckstrin homology domains to the cellular membrane, such as Akt/protein kinase B (PKB), which regulates the expression of several downstream proteins involved in cell survival and cell cycle progression [40]. Activation of $\mathrm{PI}_{3} \mathrm{~K}$ and Akt are reported to occur in ovarian, thyroid, breast, glioma and pancreatic tumor cells [41]. Through generating the second messenger phosphatidylinositol-3,4,5 -trisphosphate ( $\mathrm{PIP}_{3}$ ), $\mathrm{PI}_{3} \mathrm{~K}$ indirectly activates the protein kinase mTOR, which contains a $\mathrm{PI}_{3} \mathrm{~K}$ homology domain that suppresses apoptosis, promotes growth and drives proliferation. The mTOR kinase exists as a component of two distinct protein complexes: the mTORC1 complex phosphorylates substrates S6K at Thr389 and EIF4E at Ser209, while the mTORC2 complex itself phosphorylates Akt at Ser473 [42]. Based on these findings, the $\mathrm{PI}_{3} \mathrm{~K} / \mathrm{Akt} / \mathrm{mTOR}$ pathway is believed to be a promising therapeutic target for the treatment of cancer, and small molecules that inhibit one or more of these kinases are now being introduced into the clinic and may have some activity $[43,44]$. For example, TGF- $\beta$ increased COX-2 levels and PGE $_{2}$ secretion in prostate cancer cells which, in turn, mediate TGF- $\beta$ effects on cell migration and invasion through the activation of $\mathrm{PI}_{3} \mathrm{~K} / \mathrm{AKT} /$ mTOR pathway [45]. Thioridazine, a well-known anti-psychotic agent was found to induce apoptosis by targeting the $\mathrm{PI}_{3} \mathrm{~K} / \mathrm{Akt} / \mathrm{mTOR}$ pathway in cervical and endometrial cancer cells [46]. Moreover, the $\mathrm{PI}_{3} \mathrm{~K} / \mathrm{Akt} / \mathrm{mTOR}$ pathway was shown to be regulated by mGluR1 in neuronal cells, and the role of group I mGluRs in neuronal injury was demonstrated to be mediated by $\mathrm{PI}_{3} \mathrm{~K} /$ Akt signaling $[10,11,47,48]$. In the present study, we found that inhibition of mGluR1 by inhibitors or gene knockdown inhibited the phosphorylation of $\mathrm{PI}_{3} \mathrm{~K}, \mathrm{Akt}$ and mTOR, which was companied by decreased phosphorylation of p70S6K, a target protein of mTOR. All these data indicated that the anti-cancer effect of mGluR1 inhibition was at least partially dependent on the decreased activation of $\mathrm{PI}_{3} \mathrm{~K} / \mathrm{Akt} / \mathrm{mTOR}$ pathway.

There are several agents targeting $\mathrm{PI}_{3} \mathrm{~K} / \mathrm{Akt} / \mathrm{mTOR}$ pathway in clinical development, but most of these compounds are currently in phase I trial [49], which might be explained by the fact that blocking this signaling is often linked to different negative feedback loops. One is the increased expression of receptor tyrosine kinases, such as platelet-derived growth factor receptors (PDGFRs) and insulin receptor substrate-1 (IRS-1), resulting in increased $\mathrm{PI}_{3} \mathrm{~K}$ dependent Akt phosphorylation at Ser473, and another is the $\mathrm{PI}_{3} \mathrm{~K}$-Ras activation, which leads to an increase in mitogen-activated protein kinases (MAPKs) signaling [50, 51]. These effects attenuate the therapeutic effect of $\mathrm{PI}_{3} \mathrm{~K} / \mathrm{Akt} / \mathrm{mTOR}$ inhibitors in cancer therapy, and these issues were not fully investigated in our present study. In addition, inhibition of

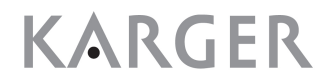


$\mathrm{PI}_{3} \mathrm{~K} / \mathrm{mTOR}$ typically induces autophagy, which facilitates cancer cell resistance to cytotoxic chemotherapy and radiation treatment $[52,53]$. Thus, the effects of mGluR1 inhibition on $\mathrm{PI}_{3} \mathrm{~K} /$ Akt /mTOR pathway related signaling feedback loops, as well as the alteration of cell autophagy after mGluR1 knockdown need to be further determined.

\section{Conclusions}

To conclude, we have demonstrated that mGluR1 inhibition using antagonists treatment or siRNA transfection induces a complex set of responses in human glioma U87 cells, including cell-cycle arrest, caspase-dependent apoptosis, invasion and migration prevention, and in vivo tumor growth inhibition. In addition, these anti-cancer effects can be nullified by the mGluRs agonist L-quisqualic acid, and the potential underlying mechanism might be related to the inhibition of $\mathrm{PI}_{3} \mathrm{~K} / \mathrm{Akt} / \mathrm{mTOR}$ signaling pathway. The usefulness of this strategy in cancer treatment and prevention should be explored in future research.

\section{Acknowledgements}

This work was financially supported by the National Natural Science Foundation of China (No. 30901539).

\section{Disclosure Statement}

The authors report no conflicts of interest.

\section{References}

1 Jemal A, Bray F, Center MM, Ferlay J, Ward E, Forman D: Global cancer statistics. CA Cancer J Clin 2011;61:69-90.

2 Louis DN, Holland EC, Cairncross JG: Glioma classification: A molecular reappraisal. Am J Pathol 2001;159:779-786.

- 3 Stupp R, Mason WP, van den Bent MJ, Weller M, Fisher B, Taphoorn MJ, Belanger K, Brandes AA, Marosi C, Bogdahn U, Curschmann J, Janzer RC, Ludwin SK, Gorlia T, Allgeier A, Lacombe D, Cairncross JG, Eisenhauer E, Mirimanoff RO: Radiotherapy plus concomitant and adjuvant temozolomide for glioblastoma. N Engl J Med 2005;352:987-996.

4 Wang ZS, Luo P, Dai SH, Liu ZB, Zheng XR, Chen T: Salvianolic acid b induces apoptosis in human glioma u87 cells through p38-mediated ros generation. Cell Mol Neurobiol 2013;33:921-928.

5 Pin JP, Acher F: The metabotropic glutamate receptors: Structure, activation mechanism and pharmacology. Curr Drug Targets CNS Neurol Disord 2002;1:297-317.

6 Masu M, Nakajima Y, Moriyoshi K, Ishii T, Akazawa C, Nakanashi S: Molecular characterization of nmda and metabotropic glutamate receptors. Ann N Y Acad Sci 1993;707:153-164.

7 Conn PJ, Pin JP: Pharmacology and functions of metabotropic glutamate receptors. Annu Rev Pharmacol Toxicol 1997; 37:205-237.

-8 Chen T, Fei F, Jiang XF, Zhang L, Qu Y, Huo K, Fei Z: Down-regulation of homer1b/c attenuates glutamatemediated excitotoxicity through endoplasmic reticulum and mitochondria pathways in rat cortical neurons. Free Radic Biol Med 2012;52:208-217.

-9 Chen T, Yang YF, Luo P, Liu W, Dai SH, Zheng XR, Fei Z, Jiang XF: Homer1 knockdown protects dopamine neurons through regulating calcium homeostasis in an in vitro model of parkinson's disease. Cell Signal 2013;25:2863-2870.

10 Chen T, Cao L, Dong W, Luo P, Liu W, Qu Y, Fei Z: Protective effects of mglur5 positive modulators against traumatic neuronal injury through pkc-dependent activation of mek/erk pathway. Neurochem Res 2012;37:983-990. 


\section{Cellular Physiology Cell Physiol Biochem 2015;35:419-432 and Biochemistry

11 Chen T, Zhang L, Qu Y, Huo K, Jiang X, Fei Z: The selective mglur5 agonist chpg protects against traumatic brain injury in vitro and in vivo via erk and akt pathway. Int J Mol Med 2012;29:630-636.

$\$ 12$ Mills CD, Johnson KM, Hulsebosch CE: Group i metabotropic glutamate receptors in spinal cord injury: Roles in neuroprotection and the development of chronic central pain. J Neurotrauma 2002;19:23-42.

-13 Ronesi JA, Huber KM: Metabotropic glutamate receptors and fragile x mental retardation protein: Partners in translational regulation at the synapse. Sci Signal 2008;1:pe6.

14 Cavalheiro EA, Olney JW: Glutamate antagonists: Deadly liaisons with cancer. Proc Natl Acad Sci U S A 2001;98:5947-5948.

15 Kalariti N, Pissimissis N, Koutsilieris M: The glutamatergic system outside the cns and in cancer biology. Expert Opin Investig Drugs 2005;14:1487-1496.

16 Stepulak A, Luksch H, Gebhardt C, Uckermann O, Marzahn J, Sifringer M, Rzeski W, Staufner C, Brocke KS, Turski L, Ikonomidou C: Expression of glutamate receptor subunits in human cancers. Histochem Cell Biol 2009;132:435-445.

17 Park SY, Lee SA, Han IH, Yoo BC, Lee SH, Park JY, Cha IH, Kim J, Choi SW: Clinical significance of metabotropic glutamate receptor 5 expression in oral squamous cell carcinoma. Oncol Rep 2007;17:81-87.

18 Iacovelli L, Arcella A, Battaglia G, Pazzaglia S, Aronica E, Spinsanti P, Caruso A, De Smaele E, Saran A, Gulino A, D'Onofrio M, Giangaspero F, Nicoletti F: Pharmacological activation of mglu4 metabotropic glutamate receptors inhibits the growth of medulloblastomas. J Neurosci 2006;26:8388-8397.

19 Pollock PM, Cohen-Solal K, Sood R, Namkoong J, Martino JJ, Koganti A, Zhu H, Robbins C, Makalowska I, Shin SS, Marin Y, Roberts KG, Yudt LM, Chen A, Cheng J, Incao A, Pinkett HW, Graham CL, Dunn K, CrespoCarbone SM, Mackason KR, Ryan KB, Sinsimer D, Goydos J, Reuhl KR, Eckhaus M, Meltzer PS, Pavan WJ, Trent JM, Chen S: Melanoma mouse model implicates metabotropic glutamate signaling in melanocytic neoplasia. Nat Genet 2003;34:108-112.

-20 Marin YE, Chen S: Involvement of metabotropic glutamate receptor 1, a g protein coupled receptor, in melanoma development. J Mol Med (Berl) 2004;82:735-749.

21 Pinheiro PS, Mulle C: Presynaptic glutamate receptors: Physiological functions and mechanisms of action. Nat Rev Neurosci 2008;9:423-436.

-22 Melchiorri D, Cappuccio I, Ciceroni C, Spinsanti P, Mosillo P, Sarichelou I, Sale P, Nicoletti F: Metabotropic glutamate receptors in stem/progenitor cells. Neuropharmacology 2007;53:473-480.

23 Nicoletti F, Battaglia G, Storto M, Ngomba RT, Iacovelli L, Arcella A, Gradini R, Sale P, Rampello L, De Vita T, Di Marco R, Melchiorri D, Bruno V: Metabotropic glutamate receptors: Beyond the regulation of synaptic transmission. Psychoneuroendocrinology 2007;32 Suppl 1:S40-45.

24 Bowie D: Ionotropic glutamate receptors \& cns disorders. CNS Neurol Disord Drug Targets 2008;7:129143.

25 Owen DR: Recent advances in the medicinal chemistry of the metabotropic glutamate receptor 1 (mglu(1)). ACS Chem Neurosci 2011;2:394-401.

26 Spooren W, Ballard T, Gasparini F, Amalric M, Mutel V, Schreiber R: Insight into the function of group i and group ii metabotropic glutamate (mglu) receptors: Behavioural characterization and implications for the treatment of cns disorders. Behav Pharmacol 2003;14:257-277.

27 Landucci E, Boscia F, Gerace E, Scartabelli T, Cozzi A, Moroni F, Mannaioni G, Pellegrini-Giampietro DE: Involvement of endocannabinoid signaling in the neuroprotective effects of subtype 1 metabotropic glutamate receptor antagonists in models of cerebral ischemia. Int Rev Neurobiol 2009;85:337-350.

-28 Markou A: Metabotropic glutamate receptor antagonists: Novel therapeutics for nicotine dependence and depression? Biol Psychiatry 2007;61:17-22.

29 Owen DR, Dodd PG, Gayton S, Greener BS, Harbottle GW, Mantell SJ, Maw GN, Osborne SA, Rees H, Ringer TJ, Rodriguez-Lens M, Smith GF: Structure-activity relationships of novel non-competitive mglur1 antagonists: A potential treatment for chronic pain. Bioorg Med Chem Lett 2007; 17:486-490.

-30 Carroll FY, Stolle A, Beart PM, Voerste A, Brabet I, Mauler F, Joly C, Antonicek H, Bockaert J, Muller T, Pin JP, Prezeau L: Bay36-7620: A potent non-competitive mglu1 receptor antagonist with inverse agonist activity. Mol Pharmacol 2001;59:965-973.

-31 Sevastyanova TN, Kammermeier PJ: Cooperative signaling between homodimers of metabotropic glutamate receptors 1 and 5. Mol Pharmacol 2014;86:492-504.

-32 Flor PJ, Battaglia G, Nicoletti F, Gasparini F, Bruno V: Neuroprotective activity of metabotropic glutamate receptor ligands. Adv Exp Med Biol 2002;513:197-223. 


\section{Cellular Physiology Cell Physiol Biochem 2015;35:419-432 and Biochemistry

33 Miller RG, Mitchell JD, Lyon M, Moore DH: Riluzole for amyotrophic lateral sclerosis (als)/motor neuron disease (mnd). Amyotroph Lateral Scler Other Motor Neuron Disord 2003;4:191-206.

-34 Miller R: Riluzole for als: What is the evidence? Amyotroph Lateral Scler Other Motor Neuron Disord 2003;4:135.

-35 Namkoong J, Shin SS, Lee HJ, Marin YE, Wall BA, Goydos JS, Chen S: Metabotropic glutamate receptor 1 and glutamate signaling in human melanoma. Cancer Res 2007;67:2298-2305.

-36 Yip D, Le MN, Chan JL, Lee JH, Mehnert JA, Yudd A, Kempf J, Shih WJ, Chen S, Goydos JS: A phase 0 trial of riluzole in patients with resectable stage iii and iv melanoma. Clin Cancer Res 2009;15:3896-3902.

-37 Datta SR, Brunet A, Greenberg ME: Cellular survival: A play in three akts. Genes Dev 1999;13:2905-2927.

-38 Shaw RJ, Cantley LC: Ras, pi(3)k and mtor signalling controls tumour cell growth. Nature 2006;441:424430.

-39 Fruman DA, Meyers RE, Cantley LC: Phosphoinositide kinases. Annu Rev Biochem 1998;67:481-507.

$\rightarrow 40$ Fresno Vara JA, Casado E, de Castro J, Cejas P, Belda-Iniesta C, Gonzalez-Baron M: Pi3k/akt signalling pathway and cancer. Cancer Treat Rev 2004;30:193-204.

41 Blanco-Aparicio C, Renner O, Leal JF, Carnero A: Pten, more than the akt pathway. Carcinogenesis 2007;28:1379-1386.

42 Copp J, Manning G, Hunter T: Torc-specific phosphorylation of mammalian target of rapamycin (mtor): Phospho-ser2481 is a marker for intact mtor signaling complex 2. Cancer Res 2009;69:1821-1827.

43 Porta C, Paglino C, Mosca A: Targeting pi3k/akt/mtor signaling in cancer. Front Oncol 2014;4:64.

44 He L, Wu Y, Lin L, Wang J, Chen Y, Yi Z, Liu M, Pang X: Hispidulin, a small flavonoid molecule, suppresses the angiogenesis and growth of human pancreatic cancer by targeting vascular endothelial growth factor receptor 2-mediated pi3k/akt/mtor signaling pathway. Cancer Sci 2011;102:219-225.

45 Vo BT, Morton D, Jr., Komaragiri S, Millena AC, Leath C, Khan SA: Tgf-beta effects on prostate cancer cell migration and invasion are mediated by pge2 through activation of pi3k/akt/mtor pathway. Endocrinology 2013;154:1768-1779.

46 Kang S, Dong SM, Kim BR, Park MS, Trink B, Byun HJ, Rho SB: Thioridazine induces apoptosis by targeting the pi3k/akt/mtor pathway in cervical and endometrial cancer cells. Apoptosis 2012;17:989-997.

47 Ledonne A, Nobili A, Latagliata EC, Cavallucci V, Guatteo E, Puglisi-Allegra S, D'Amelio M, Mercuri NB: Neuregulin 1 signalling modulates mglur1 function in mesencephalic dopaminergic neurons. Mol Psychiatry 2014

48 Hou L, Klann E: Activation of the phosphoinositide 3-kinase-akt-mammalian target of rapamycin signaling pathway is required for metabotropic glutamate receptor-dependent long-term depression. J Neurosci 2004;24:6352-6361.

49 Khan KH, Yap TA, Yan L, Cunningham D: Targeting the pi3k-akt-mtor signaling network in cancer. Chin J Cancer, 2013;32:253-265.

-50 Sarbassov DD, Ali SM, Sengupta S, Sheen JH, Hsu PP, Bagley AF, Markhard AL, Sabatini DM: Prolonged rapamycin treatment inhibits mtorc2 assembly and akt/pkb. Mol Cell 2006;22:159-168.

-51 Carracedo A, Ma L, Teruya-Feldstein J, Rojo F, Salmena L, Alimonti A, Egia A, Sasaki AT, Thomas G, Kozma SC, Papa A, Nardella C, Cantley LC, Baselga J, Pandolfi PP: Inhibition of mtorc1 leads to mapk pathway activation through a pi3k-dependent feedback loop in human cancer. J Clin Invest 2008;118:3065-3074.

52 Chen S, Rehman SK, Zhang W, Wen A, Yao L, Zhang J: Autophagy is a therapeutic target in anticancer drug resistance. Biochim Biophys Acta 2010;1806:220-229.

53 Rosich L, Colomer D, Roue G: Autophagy controls everolimus (rad001) activity in mantle cell lymphoma. Autophagy 2013;9:115-117. 